\title{
BROOKHEVEN
}

NATIONAL LABORATORY

BNL-98063-2012-CP

\section{Advancing the Deployment of Utility-Scale Photovoltaic Plants in the Northeast}

\author{
Robert Lofaro, Michael Villaran and Alessandra Colli
}

Presented at the $38^{\text {th }}$ IEEE Photovoltaic Specialists Conference

Austin, TX

June 3-8, 2012

May 2012

\section{Sustainable Energy Technologies Department/Renewable Energy Group Brookhaven National Laboratory}

\author{
U.S. Department of Energy \\ Office of Energy Efficiency and Renewable Energy
}

\footnotetext{
Notice: This manuscript has been authored by employees of Brookhaven Science Associates, LLC under Contract No. DE-AC02-98CH10886 with the U.S. Department of Energy. The publisher by accepting the manuscript for publication acknowledges that the United States Government retains a non-exclusive, paid-up, irrevocable, world-wide license to publish or reproduce the published form of this manuscript, or allow others to do so, for United States Government purposes. 


\section{DISCLAIMER}

This report was prepared as an account of work sponsored by an agency of the United States Government. Neither the United States Government nor any agency thereof, nor any of their employees, nor any of their contractors, subcontractors, or their employees, makes any warranty, express or implied, or assumes any legal liability or responsibility for the accuracy, completeness, or any third party's use or the results of such use of any information, apparatus, product, or process disclosed, or represents that its use would not infringe privately owned rights. Reference herein to any specific commercial product, process, or service by trade name, trademark, manufacturer, or otherwise, does not necessarily constitute or imply its endorsement, recommendation, or favoring by the United States Government or any agency thereof or its contractors or subcontractors. The views and opinions of authors expressed herein do not necessarily state or reflect those of the United States Government or any agency thereof. 


\title{
Advancing the Deployment of Utility-Scale Photovoltaic Plants in the Northeast
}

\author{
Robert Lofaro, Michael Villaran and Alessandra Colli
}

Brookhaven National Laboratory, Upton, NY 11973, USA

\begin{abstract}
As one of the premier research laboratories operated by the Department of Energy, Brookhaven National Laboratory (BNL) is pursuing an energy research agenda that focuses on renewable energy systems and will help to secure the nation's energy security. A key element of the BNL research is the advancement of grid-connected utility-scale solar photovoltaic (PV) plants, particularly in the northeastern part of the country where BNL is located. While a great deal of information has been generated regarding solar PV systems located in mostly sunny, hot, arid climates of the southwest US, very little data is available to characterize the performance of these systems in the cool, humid, frequently overcast climates experienced in the northeastern portion of the country. Recognizing that there is both a need and a market for solar PV generation in the northeast, BNL is pursuing research that will advance the deployment of this important renewable energy resource. BNL's research will leverage access to unique time-resolved data sets from the 37MWp solar array recently developed on its campus. In addition, BNL is developing a separate $1 \mathrm{MWp}$ solar research array on its campus that will allow field testing of new PV system technologies, including solar modules and balance of plant equipment, such as inverters, energy storage devices, and control platforms. These research capabilities will form the cornerstone of the new Northeast Solar Energy Research Center (NSERC) being developed at BNL. In this paper, an overview of BNL's energy research agenda is given, along with a description of the 37MWp solar array and the NSERC.
\end{abstract}

Index Terms - Grid integration, utility-scale photovoltaic, monitoring, performance, reliability, deployment.

\section{INTRODUCTION}

The deployment of solar photovoltaic (PV) installations in the United States has started in the Southwest area, for the favorable climatic conditions and the higher sun availability. But it is well know that photovoltaic energy can be largely used also in areas with lower sun availability, as Germany has demonstrated in Europe in the past 10 years. The Northeast area of the US has actually become another pole for application of photovoltaic energy, with states like New Jersey leading the initiative with the largest number of PV installations.

Looking toward technology innovation and grid integration for renewable energies, Brookhaven National Laboratory (BNL) has recently engaged in an energy strategy that focuses on photovoltaic (PV) system research activities. The first step has been to develop a research agenda that leverages access to data from the $37 \mathrm{MWp}$ solar array on the BNL campus. The next stage focuses on the development of the Northeast Solar
Energy Research Center (NSERC), which is expected to allow indoor and outdoor tests of PV technologies and BOS components to help address the different challenges of the interface between the intermittent PV energy production and the electric grid.

\section{SOLAR PV IN THE NoRTHEAST: BENEFITS AND CHALLENGES}

There are several factors that make solar energy attractive for the northeastern market. According to the U.S. Energy Information Administration, the average retail price of electricity in U.S. in 2010 was 9.83 cents per $\mathrm{kWh}$ [1]. However, there are several areas of the country in which the price of electricity is considerably higher than the national average, such as Alaska, California, Hawaii and the Northeast region. In 2010, two of the three States with the highest cost of electricity were located in the Northeast: Connecticut (17.39 cents per kWh) and New York (16.31 cents per kWh) [1].

Price variation by locality is due to a series of factors, such as the availability of power plants and fuels, local fuel costs, plant maintenance costs, transmission and distribution line use and maintenance, weather conditions and pricing regulations. In addition, southeastern New York, where BNL is located, has a significant amount of transmission congestion that creates an internal disparity between prices in upstate and downstate areas. Transmission capacity constraints limit the transfer of power from the north into the New York City area, especially during the peak-demand mid-afternoon hours. This situation commonly results in higher prices in New York City, on Long Island, and in the Hudson Valley.

Given the situation in the Northeast - the high concentration of population in the region, the high electricity demand and cost - the use of renewables, and especially solar PV, can be competitive.

In addition to the cost of electricity, the price of solar PV modules has decreased making solar energy more attractive. In March 2012, the average PV module price was around $2.29 \$ / \mathrm{Wp}$ (for modules $\geq 125 \mathrm{~W}$ ) and is expected to decrease further [2], helping the achievement of grid parity.

Another factor that makes solar energy attractive in the northeast is the energy policy currently being implemented in this region of the country. Presently, there are several policies in force to help the deployment of renewable energies. One policy of particular interest is the renewable portfolio standard (RPS), which was introduced with the intent to reduce carbon 
emissions. In the state of New York, the Public Service Commission (PSC) adopted the RPS in 2004. The law requires $25 \%$ of New York's electricity to come from renewable sources by 2013 , and $30 \%$ by 2015 . Within NY, entities like the Long Island Power Authority, which do not fall under the program directions, have similar programs, with goals equivalent to the RPS.

In addition to the aforementioned factors, the deployment of photovoltaic systems faces several technical challenges related to the climate conditions of the region and the integration of such a variable resource into the existing, sometimes weak or overloaded, electric grid.

The ideal grid integration design for PV systems should optimize the mutual benefits between the grid and the PV system itself. One design element that impacts integration is the power conditioning system, which acts as the interface between the dc and ac sides of the PV plant. It must be able to follow the frequency and voltage of the grid, extract maximum power from the PV array using a MPPT scheme, and deliver good-quality electric power into the grid. Distributed PV systems can have a positive impact on the grid, including local production to mitigate problems in long distance electricity transportation, and providing local reactive power support to reduce the burden of VAR compensators [3].

A major issue that remains to be resolved is the impact of the variability of the solar resource on grid stability and control. Addressing this issue will require characterization of utility-scale PV plant performance together with meteorological analysis to better understand the nature of this variability and its impact on plant output. Two main environmental variables, irradiance and temperature, affect the electricity production of a PV module: the former acting mainly on the current and the latter mainly on the voltage [4].

While a great deal of work has been performed to characterize the performance of solar PV plants in sunny, hot, arid climates, very little comprehensive data are available for the variable, temperate climatic conditions experienced in the northeast. Investigation is needed to support a large deployment of utility-scale PV installations in the northeast US area and carefully evaluate the performance of PV generators in this specific environment.

\section{OVERVIEW OF THE PHOTOVOLTAIC STATUS IN THE NORTHEAST}

The Northeast of the United States accounts for a high interest in renewable energies, and photovoltaic in particular. According to [5], the Northeast region is the second largest pole in the US in terms of the number of PV installations, even though most of them are small-size with a nominal power lower than $25 \mathrm{~kW}$. States like New Jersey, New York, Maryland, Massachusetts, and Pennsylvania are following in order after the first two ranked states, California and Arizona. Though Arizona is second in the number of installations, New
Jersey is second in terms of installed capacity. Table 1 presents solar PV installation data for states in the northeast.

New York, where BNL is located, follows immediately behind New Jersey in installed solar PV capacity. Fig. 1 shows also the situation for the various NY Counties, and it is clear that the majority of the PV plants are located along the Hudson Valley to NY City, in an area where the electricity prices are normally higher for the reasons discussed in the previous section.

TABLE I

PV INSTALLATIONS IN NORTHEASTERN STATES INFORMATION IS FROM [5].

\begin{tabular}{|l|c|c|}
\hline \multicolumn{1}{|c|}{ State } & $\begin{array}{c}\text { Number of } \\
\text { installations }\end{array}$ & $>\mathbf{2 5} \mathbf{~ k W}$ \\
\hline New Jersey & 7505 & 752 \\
\hline New York & 4388 & 468 \\
\hline Maryland & 3882 & 87 \\
\hline Massachusetts & 3690 & 421 \\
\hline Pennsylvania & 3341 & 273 \\
\hline Connecticut & 2069 & 103 \\
\hline Delaware & 1102 & 69 \\
\hline
\end{tabular}

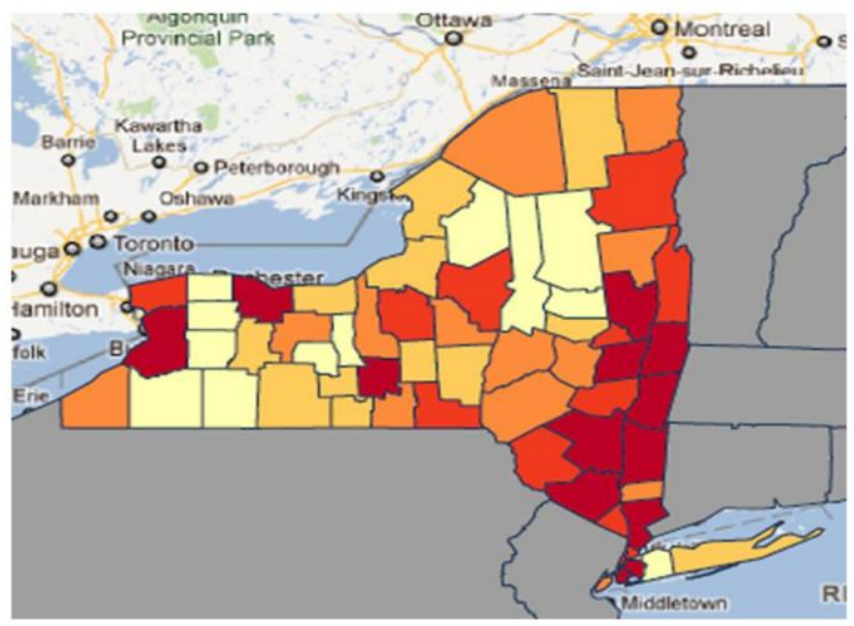

Fig. 1. Overview of the density of installations (increasing with darker colors) per county in NY state [5]. The counties with the highest number of installations are mainly located along the Hudson Valley.

The high electricity prices in the Northeast are supporting the development of utility-scale PV in this region, going in the direction of large arrays to produce local electricity and reduce costs associated with power losses, transmission and distribution. One example is the $37 \mathrm{MWp}$ plant constructed at BNL, on the Long Island.

\section{UTILITY-SCALE PV PLANT AT BNL}

The 37MWp solar array on the BNL campus is a privately owned, ground-mounted, fixed tilt PV installation. A total of 
more than 164,000 polycrystalline silicon modules were installed on about 195 acres inside the BNL campus, as shown in Fig. 2. The modules (Fig. 3) are mounted on $27^{\circ}$-tilted racks, facing south. The energy produced from the $37 \mathrm{MWp}$ field is sold directly to the local electric utility under a 20-year Power Purchase Agreement. In exchange for using DOE land to host the array, BNL is allowed access to data from the plant for research purposes.

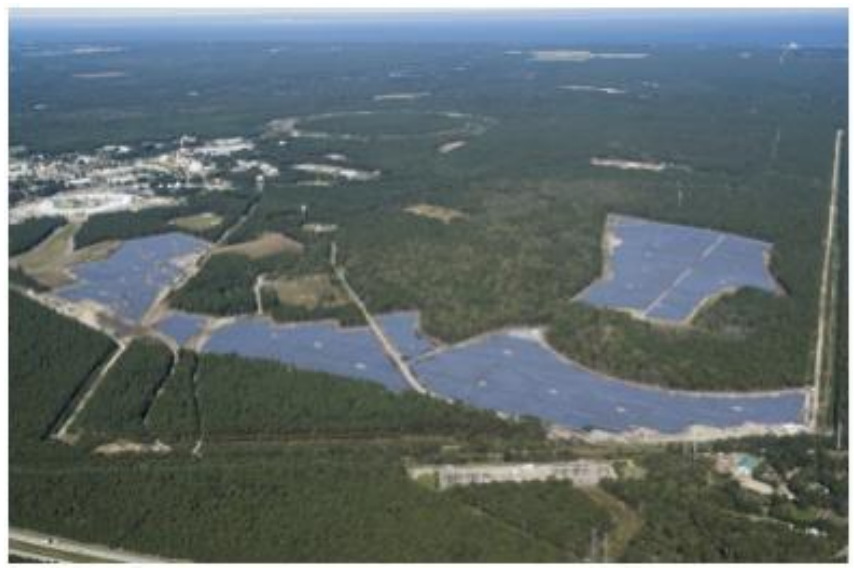

Fig. 2. An aerial view of the $37 \mathrm{MWp}$ solar array located on the BNL campus.

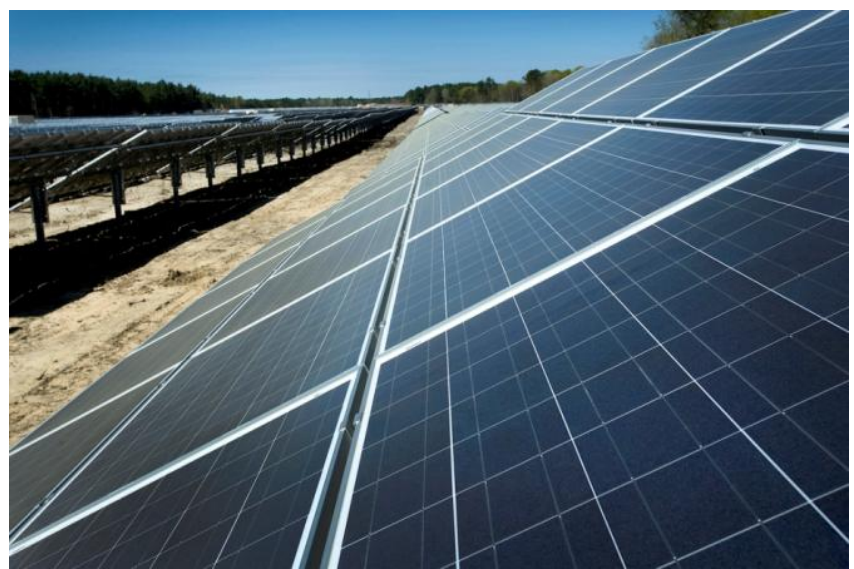

Fig. 3. View of the polycrystalline silicon modules of the 37MWp utility-scale plant at BNL.

The whole installation is divided into 25 centralized power blocks (Fig. 4), each with two SMA Sunny-Central inverters. Each inverter has a name plate rating of $625 \mathrm{~kW}$. The PV plant is expected to deliver enough energy over a yearly time span to supply 4,500 homes.

A suite of advanced research instruments has been installed in the array and data will be continuously collected across the entire field. The data will be time-resolved and will include $\mathrm{AC}$ power quality output from each inverter block and the plant collection substation, string-level DC currents and voltages (Fig. 5), global horizontal and in-plane solar irradiance at 25 different locations within the array (see the semiconductor pyranometers in Fig. 6), direct, diffuse and global components of the sun irradiance at different on-site meteorological-tower locations, sky images, temperature (ambient, modules, ground, and soil), humidity, pressure, rain gauge, wind, and humidity. These unique data sets are utilized to study performance, reliability, grid integration, and environmental impacts of utility-scale PV systems.

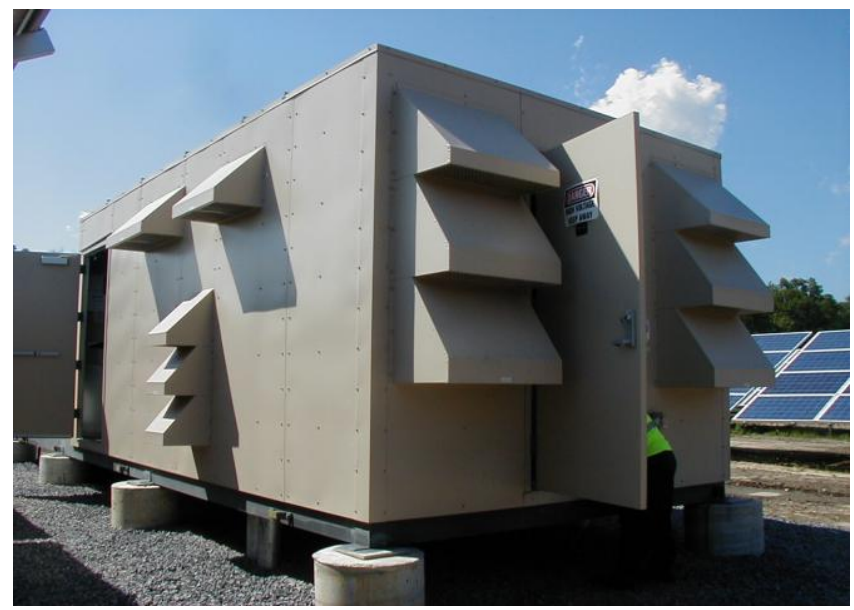

Fig. 4. The DC power is converted into $\mathrm{AC}$ at 25 centralized inverter stations.

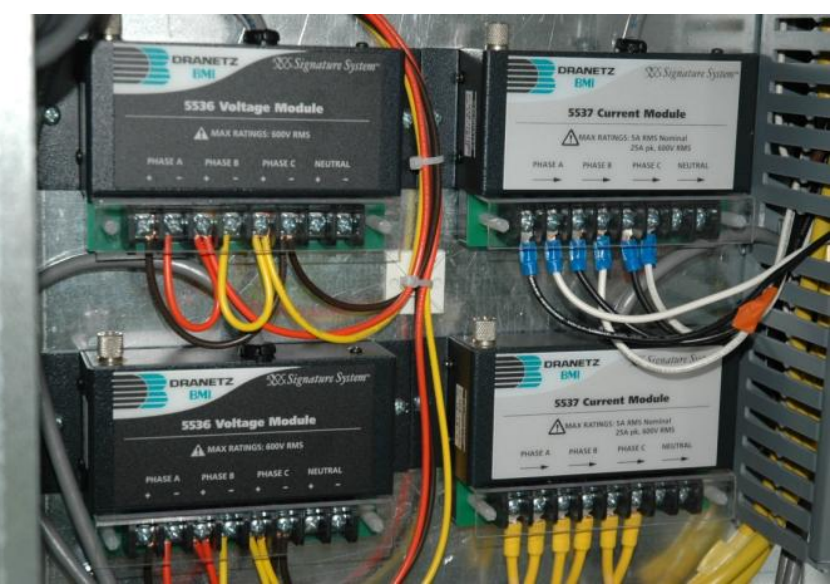

Fig. 5. Current and voltage monitoring modules from the data acquisition system on the field.

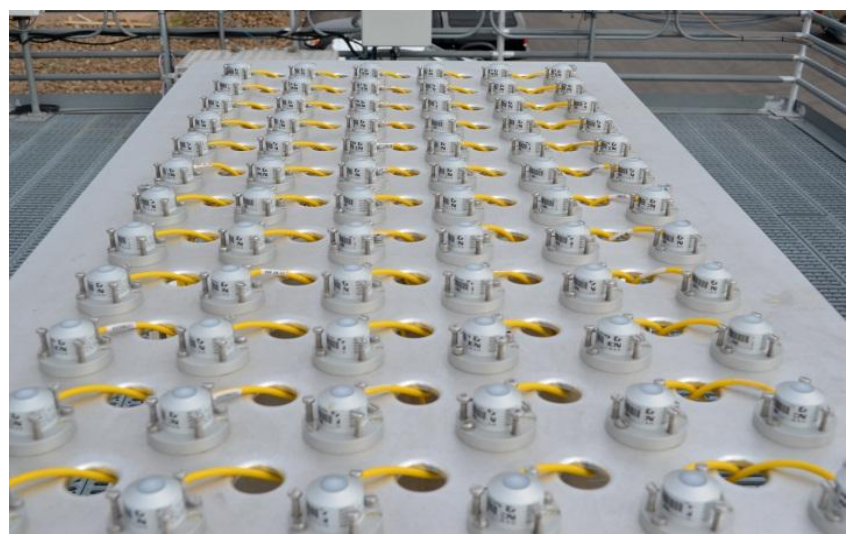

Fig. 6. The semiconductor pyranometers for irradiance detection during calibration. 


\section{THE NORTHEAST SOLAR ENERGY RESEARCH CENTER}

In parallel with the $37 \mathrm{MWp} \mathrm{PV}$ array, which is mainly devoted to commercial use, BNL is developing the Northeast Solar Energy Research Center (NSERC), which will provide test capabilities to support technology innovation and industrial development for solar PV and other renewable energy sources.

NSERC includes indoor laboratories and outdoor test capabilities to comprehensively evaluate PV technologies. The outdoor solar energy research array rated at $1 \mathrm{MWp}$ includes the use of different PV modules, from c-Si to thin-film. Space is reserved to test new and prototype modules in outdoor conditions according to international standards, evaluating their performance, reliability and degradation in the typical climate conditions of the east coast of the United States.

The research array is divided into three main areas, as indicated in Fig. 7 and 8, each with the following power capacity and intended use:

- Area 1: about $800 \mathrm{kWp}$ for utility-scale inverter testing.

- Area 2: about $100 \mathrm{kWp}$ for testing modules on tracking systems.

- Area 3: about $200 \mathrm{kWp}$ for testing different module technologies and smaller inverter typologies.

Area 1 will be the first to be completed by the end of 2012, installing mono-crystalline silicon modules.

The array is designed to be reconfigurable to enable testing system components working at a system voltage of $600 \mathrm{~V}$ or $1000 \mathrm{~V}$, to comply with both the UL and IEC requirements. It will be connected to the BNL internal electricity network to allow a flexible management for research initiatives, while also providing renewable electricity to the research campus.

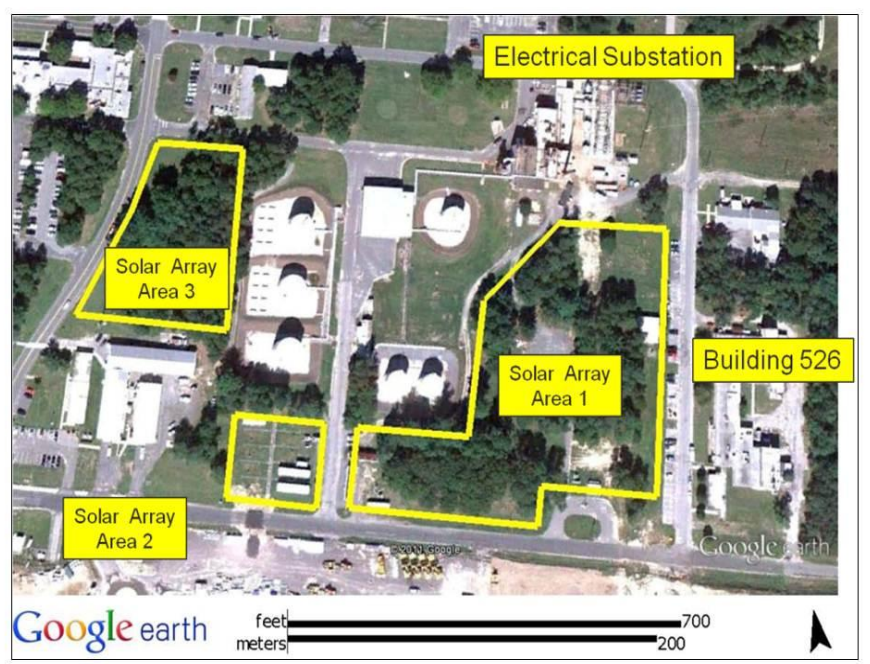

Fig. 7. Location of the solar research array at BNL. The array is divided into 3 sections as identified in the picture.

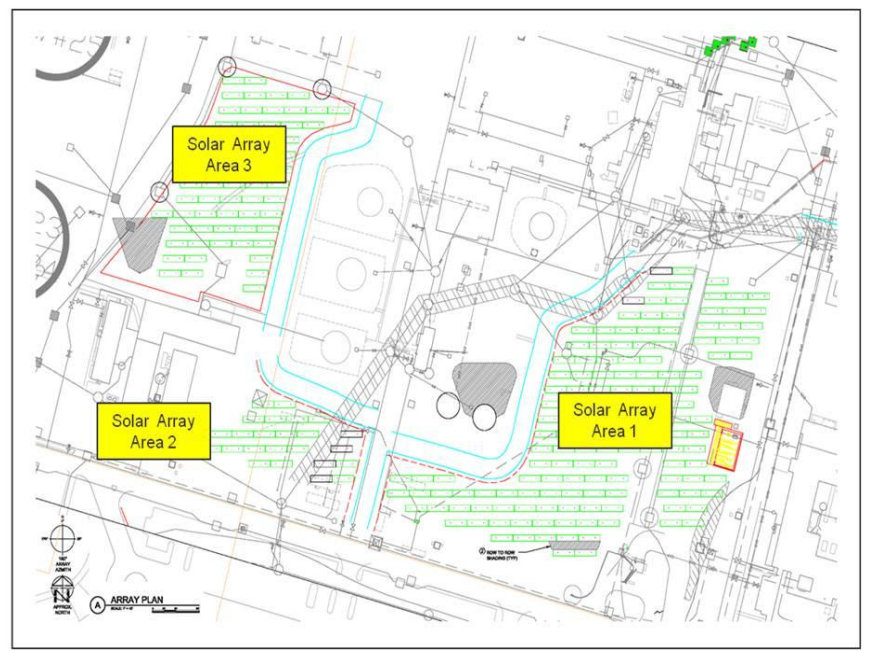

Fig. 8. Scheme of the solar research array at BNL. The modules are oriented to the South.

\section{PV PERFORMANCE AND RELIABILITY IN THE NORTHEAST}

Photovoltaic technologies perform differently in relation to the environment in which they are installed, creating a tight link between the energy production of a specific PV installation and its geographical location with the associated climate conditions.

PV technologies are affected mainly by irradiance and temperature level, but also by local environmental conditions such as wind, humidity, altitude, salty air, dust and pollution, and mounting support, including its inclination from the horizontal plane $[6,7]$.

For this reason it is very important to monitor and evaluate the performance of specific PV modules in their actual working environment, without relying only on indoor tests and label data.

The importance to consider and register the difference in a module's available power in actual operating environments different from standard test conditions (STC) has been recognized by the PV community with the publication of international standard IEC 61853 [8]. In the standard, the importance of testing modules and determining the maximum power for a set of specified rating conditions (STC), Nominal Operating Cell Temperature (NOCT), Low Irradiance Condition (LIC), High Temperature Condition (HTC), and Low Temperature Condition (LTC)) is highlighted.

\section{SOLAR ENERGY RESEARCH NEEDS IN THE NORTHEAST}

The Northeastern US operating environment has specific conditions that could affect the performance and reliability of PV technologies. Research is needed for improving the deployment of PV in the region. To comply with the specific regional needs, BNL research concerning utility-scale PV systems will focus on the following main issues: 
- Solar variability: solar irradiance data will be collected to characterize the solar resource in the region, with the purpose of being able to forecast the incoming solar energy and predict solar plants power output to support the load coverage for the grid. The characterization and management of the local solar energy resource is analyzed to define its variability and availability for PV plants in the Northeast of the US. The aim is to forecast the solar resource in a range of minutes/hours/day ahead, to be able to predict the solar plant energy output for dispatch purposes in the electric grid.

- Impact of power quality and energy production on grid management and integration: the integration of distributed solar energy resources on conventional grids and smart grid designs will be evaluated. The presence of energy storage will also be considered for better power quality and management. Connecting to the solar variability studies, being able to forecast the $\mathrm{PV}$ energy production helps to integrate PV into the grid management plan. To support the load coverage, the impact of centralized versus distributed generation will be evaluated, including the role of storage. In this context, performance and reliability studies of PV and BOS components will be conducted outdoors in the field and indoors in the laboratory, to provide improved guidelines for application of products to better adapt them to actual regional conditions.

- Environmental impacts: the impact of large utilityscale solar PV plants is evaluated on the local environment and ecology. Given the extent of utilityscale PV plants, the environmental impact will be analyzed on a short/medium/long term time span.

\section{CONCLUSION}

Deployment of utility-scale solar PV systems in the northeast is an important element for supporting the US energy security. Given the importance of evaluating PV technologies in specific environmental conditions, and analyzing their impact on the stability of transmission and distribution grid, BNL is developing capabilities and is engaged in research that will help address several of the key challenges facing the deployment of utility-scale solar PV systems in the Northeast.

Unique time-resolved research data are available from the 37MWp solar array on the BNL campus. In addition, field testing and monitoring capabilities available at the NSERC enable testing of new renewable energy technologies in compliance with best-practice guidelines and existing standards, such as the international standard IEC 61724 [9].

\section{REFERENCES}

[1]http://www.eia.gov/electricity/sales_revenue_price/index.cfm last access on 1/18/2012.

[2] Solarbuzz Solar Market Research and Analysis, http://www.solarbuzz.com/facts-and-figures/retail-priceenvironment/module-prices last access on 5/3/2012.

[3] C.V. Nayar, S.M. Islam, H. Dehbonei, K. Tan, H. Sharma, "Power Electronics for Renewable Energy Sources, part 28, pages 723-766 from the book "Power Electronics Handbook", 3rd edition, edited by M. Rashid, Elsevier, 2011.

[4] A. Luque and S. Hegedus, "Handbook of Photovoltaic Science and Engineering", second edition, ISBN: 978-0-470-72169-8, Wiley, 2011.

[5] http://openpv.nrel.gov/ last access on 5/3/2012.

[6] T. Huld, G. Friesen, A. Skoczek, R.P. Kenny, T. Sample and M. Field, E.D. Dunlop, "A power-rating model for crystalline silicon PV modules", Solar Energy Materials \& Solar Cell, 2011.

[7] J. Kurnik, M. Jankovec, K. Brecl and M. Topic, "Outdoor testing of PV module temperature and performance under different mounting and operational conditions", Solar Energy Materials \& Solar Cells, 95, pp. 373-376, 2011.

[8] International standard IEC 61853 "Photovoltaic (PV) module performance testing and energy rating", 2011.

[9] International standard IEC 61724, "Photovoltaic System Performance Monitoring - Guidelines for Measurement, Data Exchange and Analysis", 1998. 